\title{
Milieu-Adopted in vitro and in vivo Differentiation of Mesenchymal Tissues Derived from Different Adult Human CD34-Negative Progenitor Cell Clones
}

\author{
Sabine Moosmann ${ }^{a}$ Jörg Hutter ${ }^{b}$ Christian Moser ${ }^{b}$ Fritz Krombach ${ }^{b}$ \\ Ralf Huss ${ }^{a}$ \\ Institutes of a Pathology and bSurgical Research, University of Munich, Munich, Germany
}

\section{Key Words}

Adult stem cells - Mesenchymal tissue .

Microenvironment $\cdot$ Tissue aggregates

\begin{abstract}
Adult mesenchymal stem cells with multilineage differentiation potentially exist in the bone marrow, but have also been isolated from the peripheral blood. The differentiation of stem cells after leaving their niches depends predominately on the local milieu and its new microenvironment, and is facilitated by soluble factors but also by the close cell-cell interaction in a three-dimensional tissue or organ system. We have isolated CD34-negative, mesenchymal stem cell lines from human bone marrow and peripheral blood and generated monoclonal cell populations after immortalization with the SV40 large Tantigen. The cultivation of those adult stem cell clones in an especially designed in vitro environment, including self-constructed glass capillaries with defined growth conditions, leads to the spontaneous establishment of pleomorphic three-dimensional cell aggregates (spheroids) from the monoclonal cell population, which consist
\end{abstract}

S.M. and J.H. contributed equally to this work. of cells with an osteoblast phenotype and areas of mineralization along with well-vascularized tissue areas. Modifications of the culture conditions favored areas of bonelike calcifications. After the transplantation of the at least partly mineralized human spheroids into different murine soft tissue sites but also a dorsal skinfold chamber, no further bone formation could be observed, but angiogenesis and neovessel formation prevailed instead, enabling the transplanted cells and cell aggregates to survive. This study provides evidence that even monoclonal adult human CD34-negative stem cells from the bone marrow as well as peripheral blood can potentially differentiate into different mesenchymal tissues depending on the local milieu and responding to the needs within the microenvironment.

\section{Abbreviations used in this paper}

BMP bone morphogenetic protein

MMP matrix metalloproteinase

PlGF placental growth factor

VEGF vascular endothelial growth factor

\section{KARGER}

Fax + 41613061234 E-Mail karger@karger.ch www. karger.com
(C) 2005 S. Karger AG, Base

1422-6405/05/1793-0091\$22.00/0

Accessible online at:

www. karger.com/cto
Ralf Huss, MD

Institute of Pathology, University of Munich, Thalkirchner Strasse 36 DE-80337 Munich (Germany)

Tel. +49 895160 4953, Fax +498951604043

E-Mail Ralf.Huss@patho.med.uni-muenchen.de 


\section{Introduction}

The plasticity or transdifferentiation potential of adult stem cells and their implications for regenerative medicine in the future is still subject to controversy among scientist and clinicians. Adult hematopoietic stem cells can be isolated from the bone marrow, peripheral blood and umbilical cord blood for immediate and successful clinical use. An increasing number of reports have suggested that adult stem cells have a considerable degree of pluripotency and plasticity, which apparently allows their differentiation into a variety of tissue-specific progenitors in vivo and their application in organ regeneration after injury or disease [Horwitz et al., 1999; Pittenger et al., 1999]. We have cloned various adult stem cell lines from the bone marrow and the peripheral blood in different species. All stem cell lines consisted of two populations after cultivation in vitro: a fibroblast-like and predominately quiescent (non-active) population and a potentially active subpopulation, which can eventually differentiate into hematopoietic, endothelial and mesenchymal precursor cells. One observation was that CD34-negative, fibroblast-like cells from the canine bone marrow can give rise to CD34-positive hematopoietic precursor cells [Huss et al., 1995; Huss, 1998]. With a cloned adult murine cell line from peripheral blood mononuclear cells, we achieved complete and long-term hematopoietic recovery in syngeneic mice after myeloablative therapy [Lange et al., 1999]. Similarly, a monoclonal cell line from canine peripheral blood was also used for an autologous transplantation resulting in cells co-expressing mesenchymal markers in vitro and in vivo, e.g. osteocalcin [Huss et al., 2000]. The monoclonal human cell line also showed mesenchymal differentiation and expressed type I and type $\mathrm{V}$ collagen along with osteocalcin in vitro, suggestive of its osteogenic potential [Thalmeier et al., 1996]. Human monoclonal cell lines are also composed of a small Rho123low, CD34-positive subpopulation and a Rho123 $3^{\text {high }}$, CD34-negative major population [Conrad et al., 2002]. The hematopoietic transcription factors GATA$1,-2$ and -3 were only expressed in the Rholow population, while the Rhohigh population expressed vascular endothelial growth factor (VEGF) and Tie-1 [Ziegler et al., 1999], which has already been demonstrated on primitive stem cells. Tie-1 is also present on endothelial cells and hematopoietic progenitors, which draws attention to the hemangioblast as a potential pluripotent stem cell, with plasticity being between hematopoietic and mesenchymal lineages [Baron, 2001], especially because all cells co-expressed bone morphogenetic protein (BMP) receptor 1A. Based on previous observations and the molecular phenotype of available human adult cell lines [Thalmeier et al., 2001; Conrad et al. 2002], we investigated the possibility whether potentially multipotent and monoclonal adult stem cells can respond adequately to inductive in vitro conditions when grown in three-dimensional spheroids, as demonstrated for embryonic stem cells [Zhang et al., 2001]. The consecutive use of an appropriate in vivo model for an extended differentiation of those preformed aggregates could give further insight into the biology and plasticity of adult stem cells, which might participate in tissue regeneration and organ maintenance.

\section{Materials and Methods}

\section{Cell Lines}

We used the CD34-negative fibroblast-like cell lines L88/5 isolated from bone marrow cells [Thalmeier et al., 1996] and the peripheral blood-derived human CD34-negative CD105-positive cell line V54/2 [Conrad et al., 2002]. All different cell lines were cloned after immortalization with the SV40 large T-antigen. The random insertion of usually 9-11 copies did not change the biological behavior of any cell line as observed over the past 4 years [unpubl. observation].

\section{Three-Dimensional Aggregate Cultures}

Tissue aggregates were obtained here using glass capillaries, which enables close cell-cell interaction of adult stem cells during development and differentiation. Cells were cultivated for about 4-6 weeks in glass capillaries $(0.5-1.0 \mathrm{~mm}$ in diameter and $30-50 \mathrm{~mm}$ long), placed in tissue culture flasks (Corning Costar, Cambridge, Mass., USA), grown in RPMI (Gibco Life Technologies, Eggenstein, Germany) supplemented with $10 \%$ fetal calf serum, $4 \mathrm{mmol} / \mathrm{l} L$ glutamine and penicillin $(60 \mathrm{mg} / \mathrm{l}) /$ streptomycin $(100 \mathrm{mg} / \mathrm{l})$. Cells were incubated at $37^{\circ} \mathrm{C}$ in a humidified incubator with $5 \% \mathrm{CO}_{2}$. Medium was changed 2-3 times per week. Within a 30-day period, three-dimensional aggregates grew out of the capillaries. These aggregates were transferred to a 96-well plate and cultivated for further 10-14 days. During this cultivation interval, the aggregates attached to the plastic surface and fibroblast-like cells grew out as a cell layer. Because of ample medium consumption, cell bodies were transferred to 24-well plates and 6 wells, respectively. At this time, a $\mathrm{Ca}_{2} \mathrm{PO}_{4-}$ supplemented mineral solution (250 mM; Druefusan; Syxyl, Cologne, Germany) as well as BMP4 (10 ng/ml; R\&D, Wiesbaden, Germany) were added to the culture media. Afterwards, cell aggregates were cultured as described above.

\section{Immunhistostaining of Paraffin-Embedded Sections}

Explanted and in vitro generated tissue aggregates were fixed overnight in 4\% PBS buffered formalin and embedded in paraffin. 2to $5-\mu \mathrm{m}$ sections were stained with different commercially available and human specific antibodies. Using biotinylated detection systems, sections were treated with $0.3 \%$ hydrogen peroxide to block endogenous peroxidase activity. Deparaffinized slides were incubated with either CD31 (dilution: 1:30; Dako, Hamburg, Germany), osteocalcin (dilution: 1:400; Biotrend, Cologne, Germany), CD34 (dilution: 1:50; BD-Pharmingen, Heidelberg, Germany) or CD117 and VEGF (dilution: 1:100; Dako, Hamburg, Germany). CD31 and osteocalcin were detected by an AP-conjugated detection system 
(Dako). The signal was finally developed using Fast Red (Sigma, Deisenhofen, Germany) as substrate. CD34, VEGF and CD117 were sequentially incubated with a biotinylated detection system (Dako). Visualization was achieved with 3-amino-9-ethylcarbazol substrate (Sigma).

\section{In situ Hybridization}

Deparaffinzed 6- to $8-\mu \mathrm{m}$ sections were pretreated with a Target Retrieval Solution (Dako) at $97^{\circ} \mathrm{C}$ in a water bath for $15 \mathrm{~min}$. Subsequent sections were pretreated with $0.2 \%$ protease $\mathrm{E}$ (Sigma) at $37^{\circ} \mathrm{C}$ for $2 \mathrm{~min}$ and fixed in $4 \%$ paraformaldehyde for $10 \mathrm{~min}$. Endogenous peroxidase activity was blocked using triethanolamine/acetic acid anhydride (Sigma). Sections were dehydrated and briefly denaturated at $96^{\circ} \mathrm{C}$ for 2 min and incubated overnight at $37^{\circ} \mathrm{C}$ with the $\mathrm{C} 17$ probe. The biotinylated probe was detected using the ABC-Elite Kit (Vector, Burlingame, Calif., USA) and visualized with Nova Red (Vector).

\section{Reverse Transcription-Polymerase Chain Reaction}

For first-strand synthesis 1-2 $\mu \mathrm{g}$ RNA from L88/5 and V54/2 cells were dissolved in $9.7 \mu \mathrm{l}$ volume together with $2 \mu \mathrm{l}$ random hexamers (100 $\mu M$ stock, Amersham Pharmacia Biotech) and incubated at $65^{\circ} \mathrm{C}$ for $20 \mathrm{~min}$, before the samples were centrifuged for $10 \mathrm{~s}$ and placed on ice. In a second step, $5 \times$ first-strand buffer (Gibco kit catalogue No. 28025-013) was mixed with $2 \mu \mathrm{l} 0.1 \mathrm{M}$ 1,4-dithio- $D L$ threitol (Sigma), $1 \mu \mathrm{l}$ M-MLV reverse transcription, $0.8 \mu 125 \mathrm{mM}$ dNTPs (Amersham Pharmacia Biotech) and $0.5 \mu 1$ RNasin (Promega). This mixture was added to the solution from step 1 and incubated together at $37^{\circ} \mathrm{C}$ for $90 \mathrm{~min}$, then at $70^{\circ} \mathrm{C}$ for $10 \mathrm{~min}$ and finally stored at $-20^{\circ} \mathrm{C}$. The PCR reaction was performed in tubes with a 0.2 -ml-thin wall with $2.5 \mu \mathrm{l}$ of $10 \times$ buffer II, $1.5 \mu \mathrm{MgCl}_{2}$, $0.5 \mu \mathrm{l}$ dNTPs $(10 \mu M$ stock $), 0.2 \mu \mathrm{l}$ Amplitaq gold and $1 \mu \mathrm{l}$ firststrand cDNA or water (negative control) or RNA (no reverse transcription control) in $18.3 \mu \mathrm{l}$ water. $1 \mu \mathrm{l}$ of each forward and reverse primer from the designed transcription product was added from a $25-\mu M$ stock solution. The PCR program ran for 35 cycles with an annealing temperature of $58^{\circ} \mathrm{C}$ for $30 \mathrm{~s}$ and an amplification temperature of $70^{\circ} \mathrm{C}$ also for $30 \mathrm{~s}$. The samples were then run on a $2 \%$ agarose gel. Primer sequences are available from the authors. The osteocalcin primers were 5'-CCG GGC CGT AGA AGC GCC GAT A-3' and 5'-ATG GCC CTC ACA CTC CTC G-3' (297 bp) and for osteopontin 5'-CAT TGA CTC GAA CGA CTC TG-3' and 5'-ATT CTA TGG TTG GGG AAG GGT-3' (354 bp).

\section{Electron Microscopy}

For scanning electron microscopy, adult stem cells were grown in chamber slides on circular coverslips and fixed in Karnovsky/Karnovsky 2 as described and published elsewhere [Huss, 1997]. For transmission electron microscopy, tissue aggregates were fixed in $0.5 \%$ glutaraldehyde overnight and processed as described.

Transplantation into Dorsal Skinfold Chambers as a Host Site

Male CD-1 nude mice (25-30 g; Charles River, Sulzfeld, Germany) were used for the experiments, which have been approved by the Bavarian Ethics Committee on Animal Rights and Protection. Surgery necessary for the implantation of chambers and the transplantation of stem cells aggregates was done under aseptic conditions with the animals under general anesthesia (i.m. ketamine $125 \mathrm{mg} / \mathrm{kg}$ body weight, i.m. xylazine $15 \mathrm{mg} / \mathrm{kg}$ body weight).

Dorsal skinfold chambers were fitted to the animals as described previously [Lehr et al., 1993]. A skinfold along the spine was ex- tended and sandwiched between two symmetrical titanium frames. A circular area $(\varnothing 15 \mathrm{~mm})$ of one layer of the skinfold was completely resected, and the exposed inside of the opposing layer with a striated skin muscle on top was covered by a removable coverslip hold by one frame. Following a 48-hour recovery period, the coverslip was removed, one aggregate of stem cells was placed on the striated muscle tissue, and the chamber was closed again. From then on, animals were housed in an incubator $\left(34-37^{\circ} \mathrm{C}\right.$, air humidity $80 \%$; Dräger 8000 NC, Lübeck, Germany) with free access to tap water and standard chow food.

Graft size and the process of vascularization were investigated daily by intravital microscopy (Zeiss Axiotech, Oberkochen, Germany). Awake animals were immobilized in plastic tube restrainers, and the skinfold preparations were attached to the microscopic stage. Pictures obtained by transillumination $(395-440 \mathrm{~nm})$ were recorded with a CCD-video camera (Pieper FK 6990 IQ-S, Schwerte, Germany) and videotaped. Samples of the striated skin muscle bearing the transplant were taken at various time points after the first appearance of graft vascularization.

\section{Transplantation into Murine Soft Tissue as a Host Site}

The skin at the back was incised along the right scapular line. Stem cell aggregates were transplanted into the subcutaneous soft tissue; thereafter the incision was closed by suture. For the following 6 days, animals were housed in an incubator with free access to standard chow food and tap water. On day 7, the incision was reopened, the subcutaneous area was explored, and aggregates were harvested.

\section{Results}

\section{Adult Human Stem Cell Clones}

More than 2 decades ago, a highly disputed discussion started whether there is a common CD34-negative precursor cell for CD34-positive hematopoietic stem cells and CD34-negative (mesenchymal) stromal elements [Singer et al., 1984], which initiated the discussion of the plasticity of adult stem cells. Therefore, we decided to generate adult stem cell clones from different sources in different species [Huss, 2000] to address the issue of plasticity within a clonal cell population. We used cell lines from human bone marrow [Thalmeier et al., 1996] and peripheral blood [Conrad et al., 2002] to perform our experiments. The human stem cell lines predominantly grow adherent as fibroblast-like cells, while few nonadherent CD34-positive cells are only loosely attached to the underlying fibroblast-like cells, which spontaneously emerge from the underlying CD34-negative progenitors as published previously [Conrad et al., 2002] (fig. 1).

\section{Osteogenesis and Small Diameter Vessel Formation in Three-Dimensional Spheroids}

As published previously, the development of threedimensional tissue aggregates is advantageous or even a 

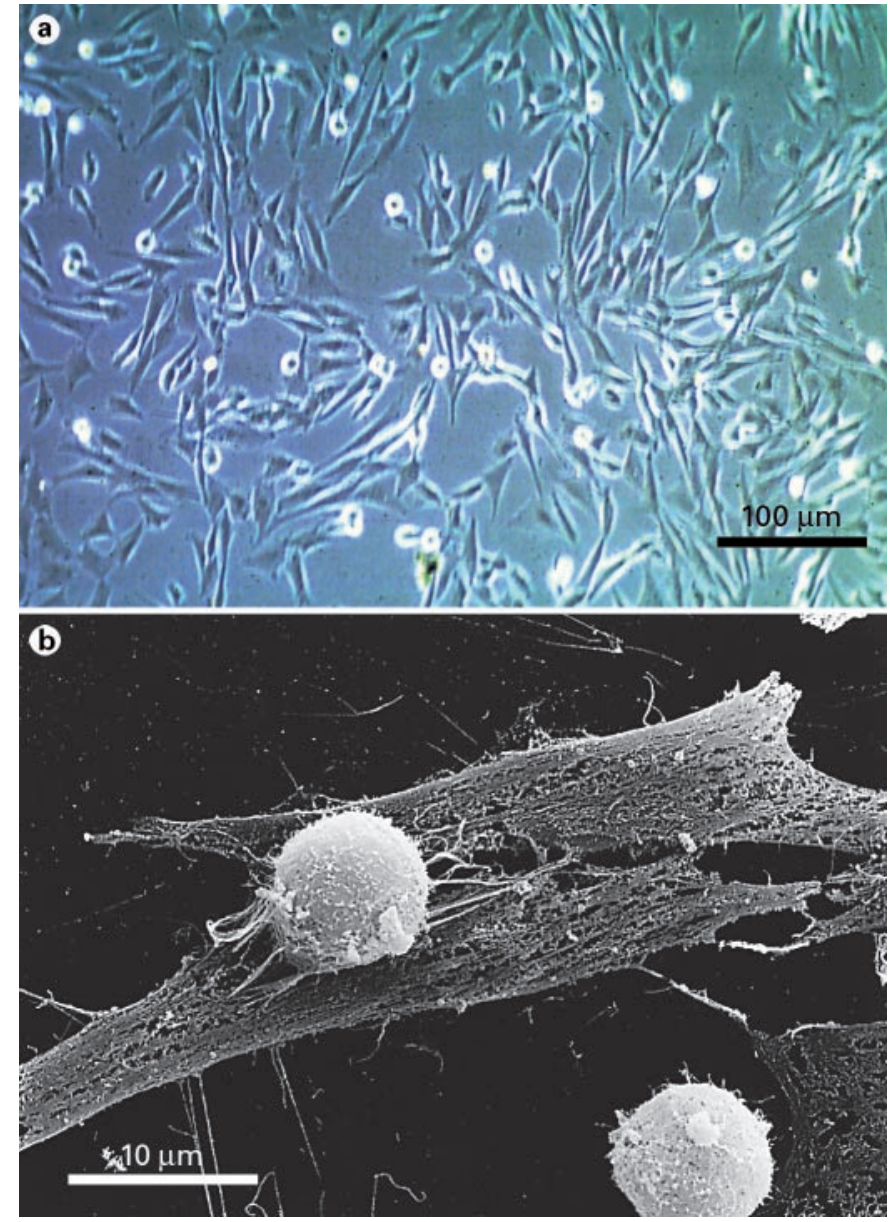

Fig. 1. Morphology of the CD34-negative adult progenitor cell clone L88/5. a Most of the cells of the monoclonal CD34-negative stem cell from the L88/5 cell line grow adherent as fibroblast-like and spindleshaped cells, while fewer cells in culture are non-adherent, CD34positive cells, spontaneously emerging from the underlying CD34negative progenitors [Conrad et al., 2002]. Those CD34-positive cells can also return to a more quiescent state as CD34-negative fibroblast-like, adherent cells. b Scanning electron microscopy of the bone-marrow-derived CD34-negative cell line L88/5. The nonadherent CD34-positive cell is loosely attached to the underlying spindle-shaped CD34-negative cell by some fibers of the extracellular matrix.

necessary precondition to establish the formation of human bone from adult stem cells [Kale et al., 2000]. Although small cell clusters or spheroids can develop spontaneously on a confluent stem cell layer in vitro, we constructed our own glass capillaries for the generation of tissue aggregates. As shown in figure 2a, 10-20 cells from a CD34-negative adult cell line were placed into such a glass capillary, where they grew continuously (fig. 2b) until the development of three-dimensional spheroids at
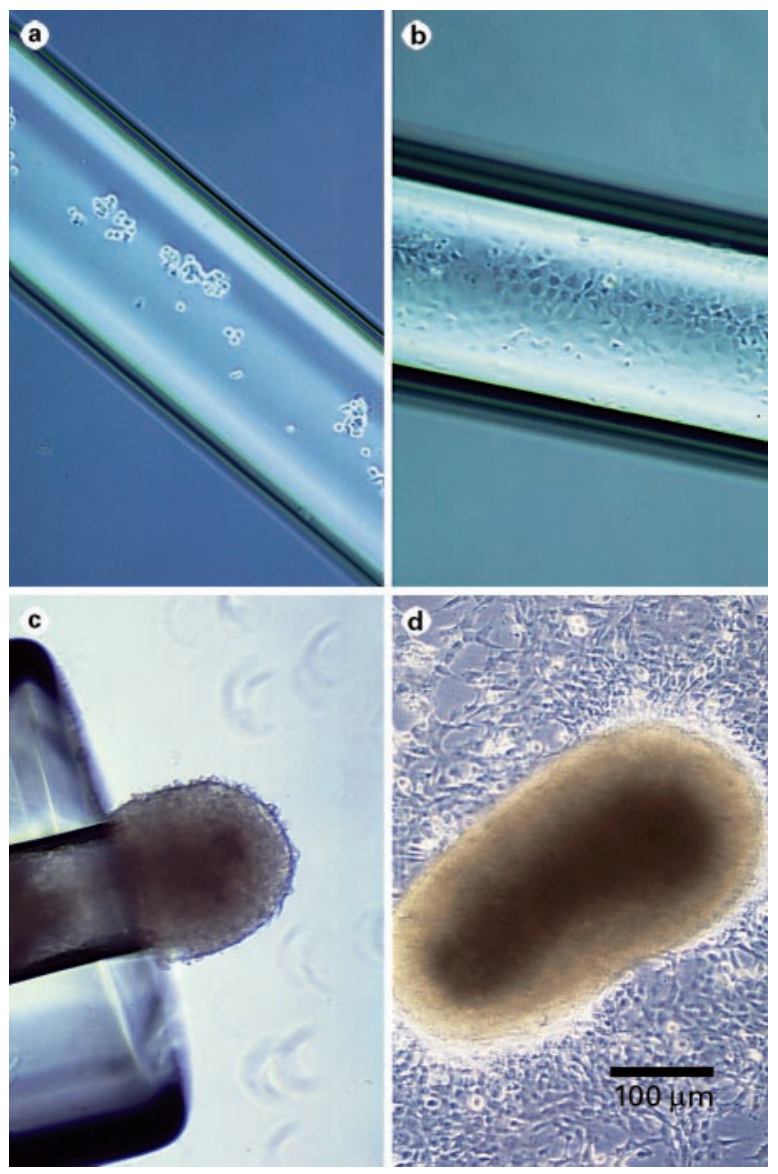

Fig. 2. Spontaneous differentiation of a monoclonal bone-marrowderived progenitor cell line in a glass capillary. a 10-20 cells of each stem cell clone were implanted into a $0.5-\mathrm{mm}$-large glass capillary. b The cells continue to grow and fill up the intracapillary space within 2-3 weeks. c After 4 weeks, three-dimensional spheroids grow out of both open ends of the glass capillary. $\mathbf{d}$ These three-dimensional spheroids also consist of a fibroblast-like cell type after continuous growth in a cell culture dish.

the tip end after 3-4 weeks (fig. 2c). Morphologically identical fibroblast-like cells emerged from the up to 10-mm-large tissue aggregates when placed into a tissue culture dish similar to the growth conditions of the primary cells (fig. 2d). Although, the in vitro generated threedimensional tissue aggregates consisted of the pre-seeded CD34-negative stem cells, serial sections of the formalinfixed and paraffin-imbedded spheroids (fig. 3a) revealed a distinct organization of the tissue aggregates, with distinguishable areas of osteogenesis and neoangiogenesis (fig. 3b). The aggregate showed an internal positive staining with antibodies against osteocalcin (fig. 3c), while cells 

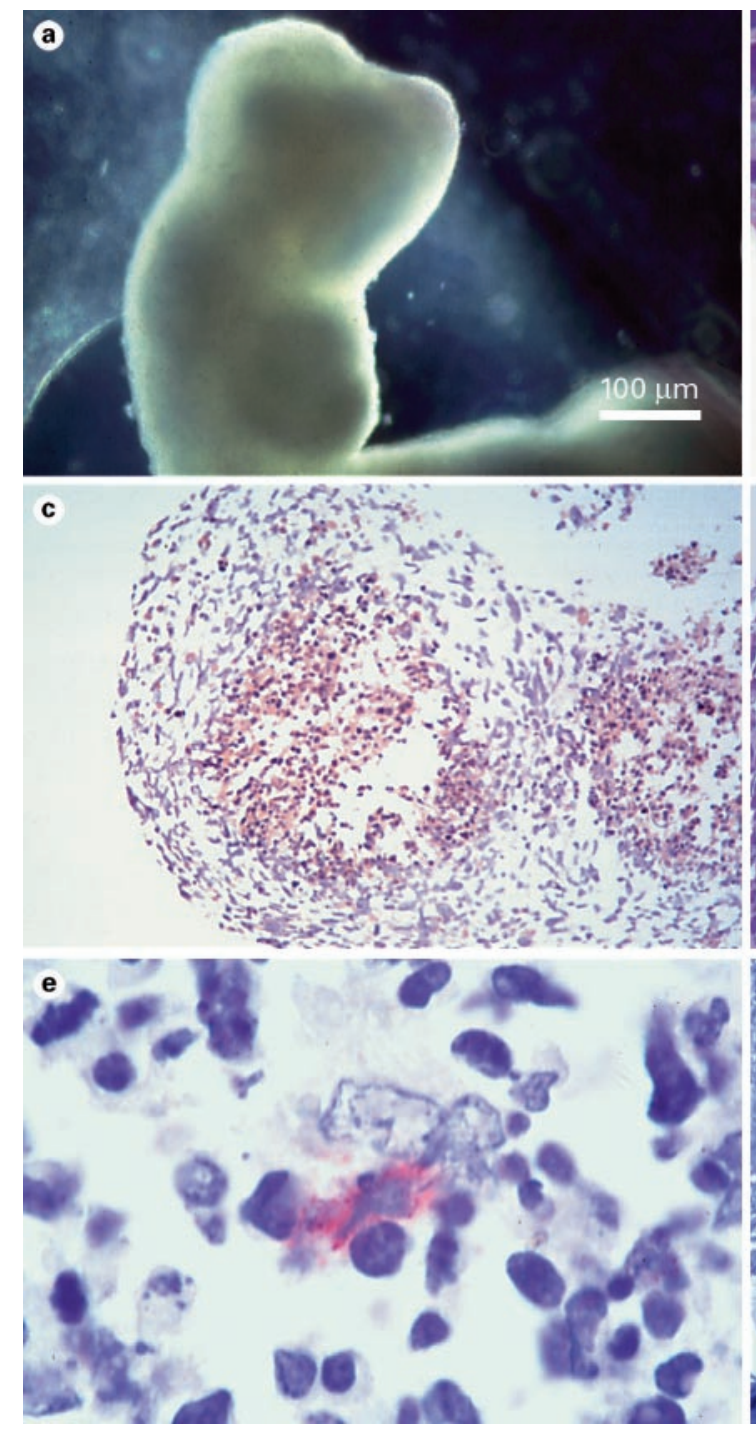


Fig. 3. Immunohistostaining and transmission electron microscopy of paraffin-embedded three-dimensional spheroids. a Complete three-dimensional spheroid derived from the clonal progenitor cell line and grown in a defined milieu after placement into a tissue culture dish. b Spheroids were fixed in buffered formalin and embedded in paraffin before preparing serial sections. Conventional HE staining already shows two distinct areas: a central area of the aggregate with cells that contain more cytoplasm with smaller nuclei (upper right) and a ribbon-like structure with more cuboidal-shaped cells with larger nuclei on the outside of the aggregate (lower left). c The inner 'nucleus' stains positive with antibodies against osteocalcin and MMP-9 (not shown), suggesting the osteogenic potential of these more cuboidal cells in this area. d Instead, the outer 'ribbon' of the aggregate contains predominantly VEGF-positive spindle-shaped cells, which is the typical feature of CD34-negative stem cells undergoing endothelial differentiation [Huss et al., 2004]. e Among the VEGF-positive angioblasts, there are already some mature endothelial cells expressing PECAM-1 (CD31). f Electron microscopy shows the formation of small capillary-like structures, while other cells present condensed chromatin. of the outer area revealed expression of the angiogenic marker VEGF (fig. 3d) and matrix metalloproteinase (MMP)-9 (not shown). Neoangiogenesis was confirmed by the expression of CD31 (PECAM-1) on rare endothelial cells (fig. 3e) and the formation of small-diameter neovessels (fig. 3f), which is characteristic of CD34-nega- tive stem cells undergoing spontaneous differentiation [Huss et al., 2004]. The organization of the in vitro generated three-dimensional spheroids with areas of mineralization and endothelial differentiation occurred spontaneously at the given conditions, but the addition of $\mathrm{Ca}_{2} \mathrm{PO}_{4}$-rich medium supplemented with BMP4 shifted 

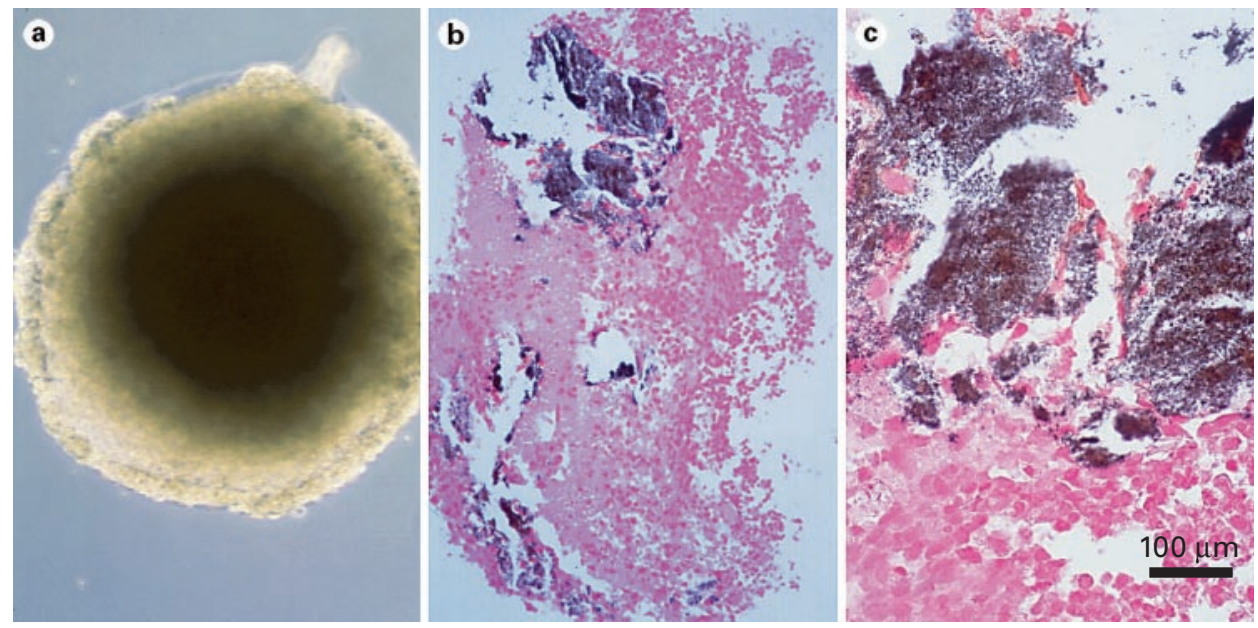

Fig. 4. Mineralization of three-dimensional spheroids after applying osteogenic cell culture conditions. a Stem cell aggregates after additional incubation in $\mathrm{Ca}_{2} \mathrm{PO}_{4}$-supplemented mineral solution and BMP4 showing a different gross appearance after 2 weeks in culture. b, c von Kossa staining showing dark areas of mineralization. Osteocalcin (d) and osteopontin (e) mRNA in $\mathrm{L} 88 / 5$ and $\mathrm{V} 54 / 2$ cell clones.
L88/5 V54/2

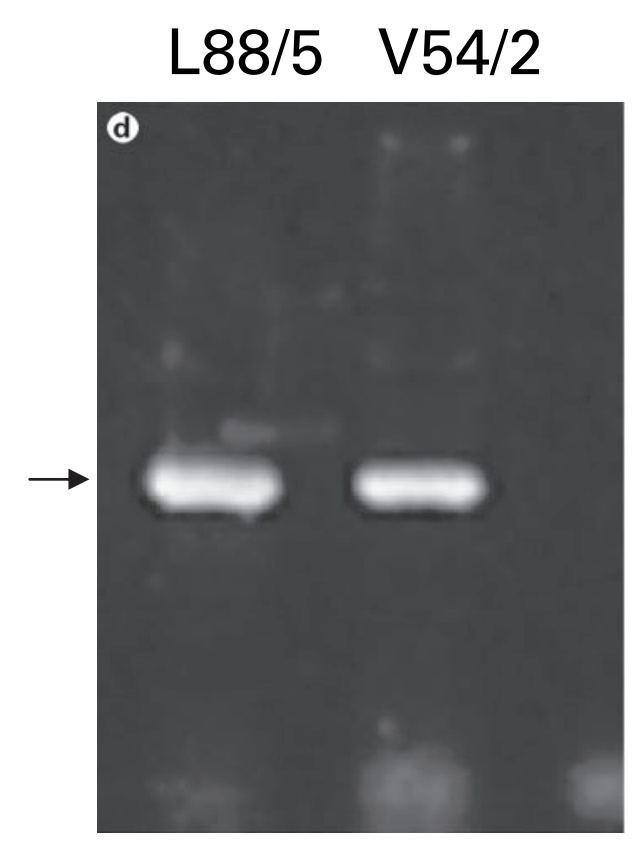

L88/5 V54/2

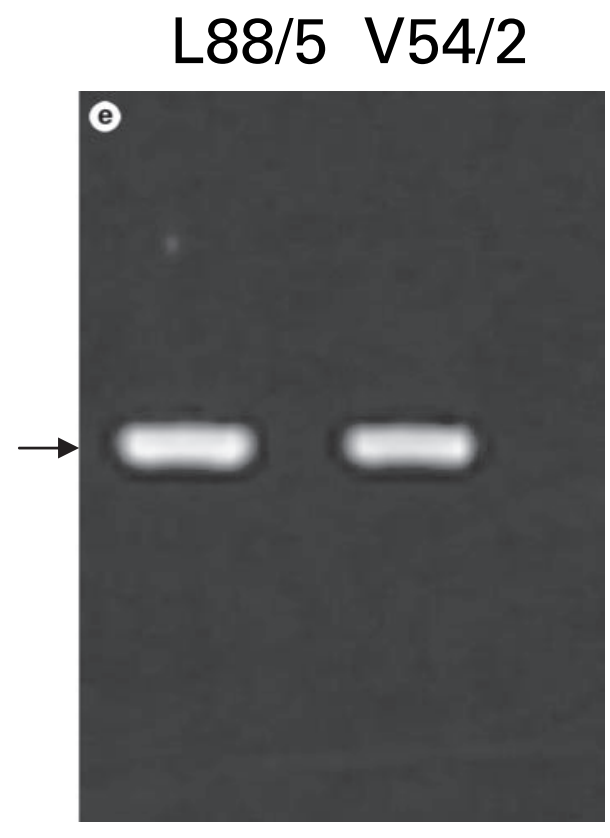

the differentiation entirely towards areas of mineralization (fig. 4a-c) and the expression of human specific mRNA for osteocalcin and osteopontin (fig. 4d, e).

\section{Milieu-Dependent Differentiation in vivo}

The spontaneous development of heterogeneous mesenchymal tissue aggregates from a single adult stem cell clone in vitro suggested the transfer of the three-dimensional spheroids into an in vivo model to investigate further maturation of the preformed and predifferentiated tissue. The subcutaneous implantation into the soft tissue close to the back muscle of a nude recipient mouse did not induce any differentiation of the transplanted cells into mature tissue (fig. 5a). Instead, a heterogeneous distribution of CD31-positive endothelial cells along with osteocalcin-positive bone precursors, c-kit-positive hematopoietic progenitors and CD34-positive angiogenic cells was detected (fig. 5b-e) without evidence of organ formation. In situ hybridization with a human centromer-specific probe revealed the coexistence of murine and human tissue, particularly at the site of the transplanted tissue and murine site of implantation (fig. 5f). The sole transplantation of the in vitro generated tissue into a random site of a nude mouse was not sufficient to induce maturation or committed differentiation. 

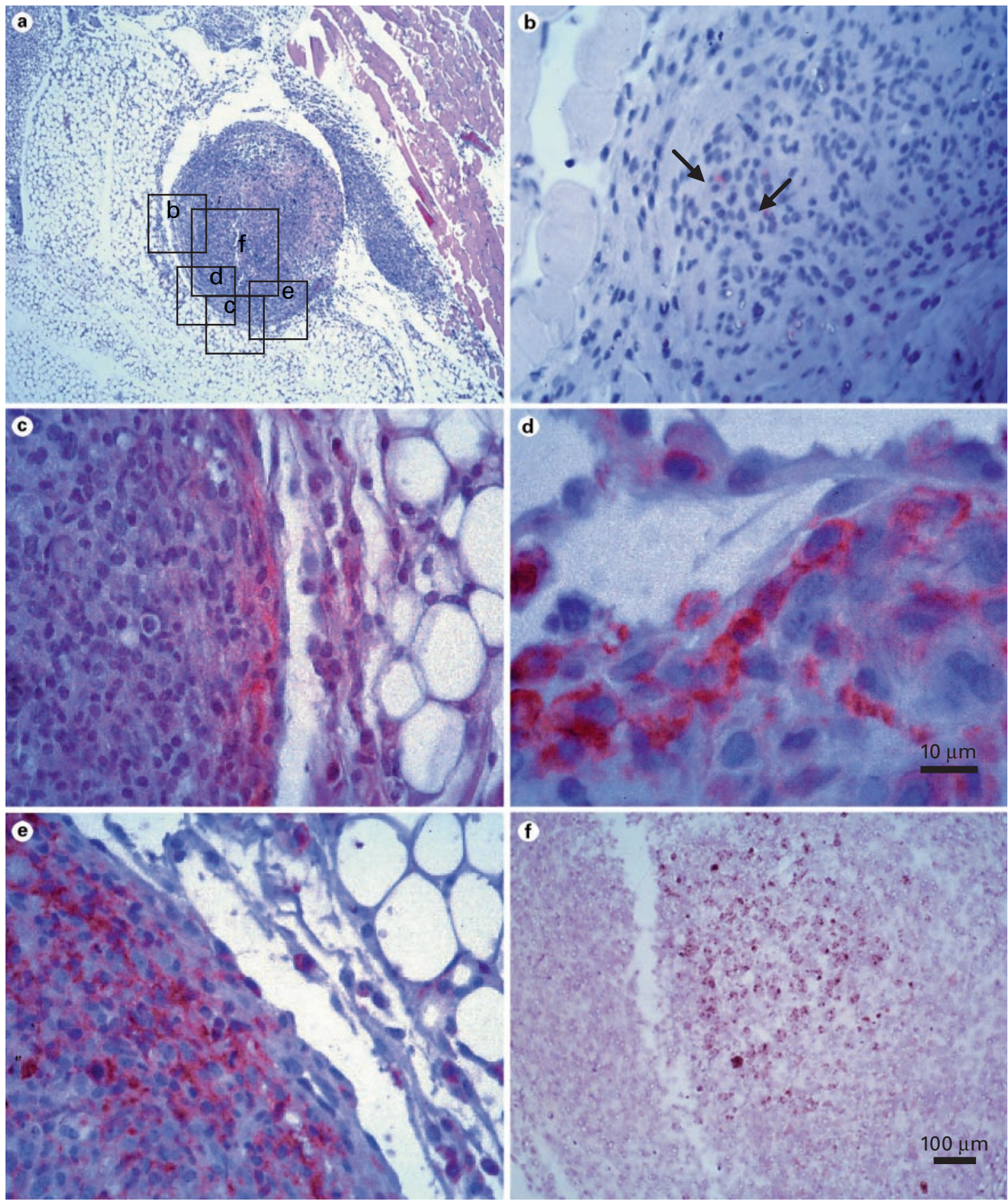

Fig. 5. Histology and in situ hybridization of subcutaneous soft tissue implants. a HE staining of the implanted human cellular aggregate between the host (murine) muscle and adipose tissue 7 days after transplantation. b Enlargement still shows few CD34-positive cells in the grafted aggregate. c, d Osteocalcin-positive cells, which coexpress c-kit (CD117) indicating activation. e As shown prior to implantation, the majority of CD31-positive endothelial cells are located circular around the transplanted cell aggregate to anastomose with host-derived vessels. $f$ In situ hybridization with the human centromer-specific $\mathrm{C} 17$ probe reveals the presence of implanted human cells. 

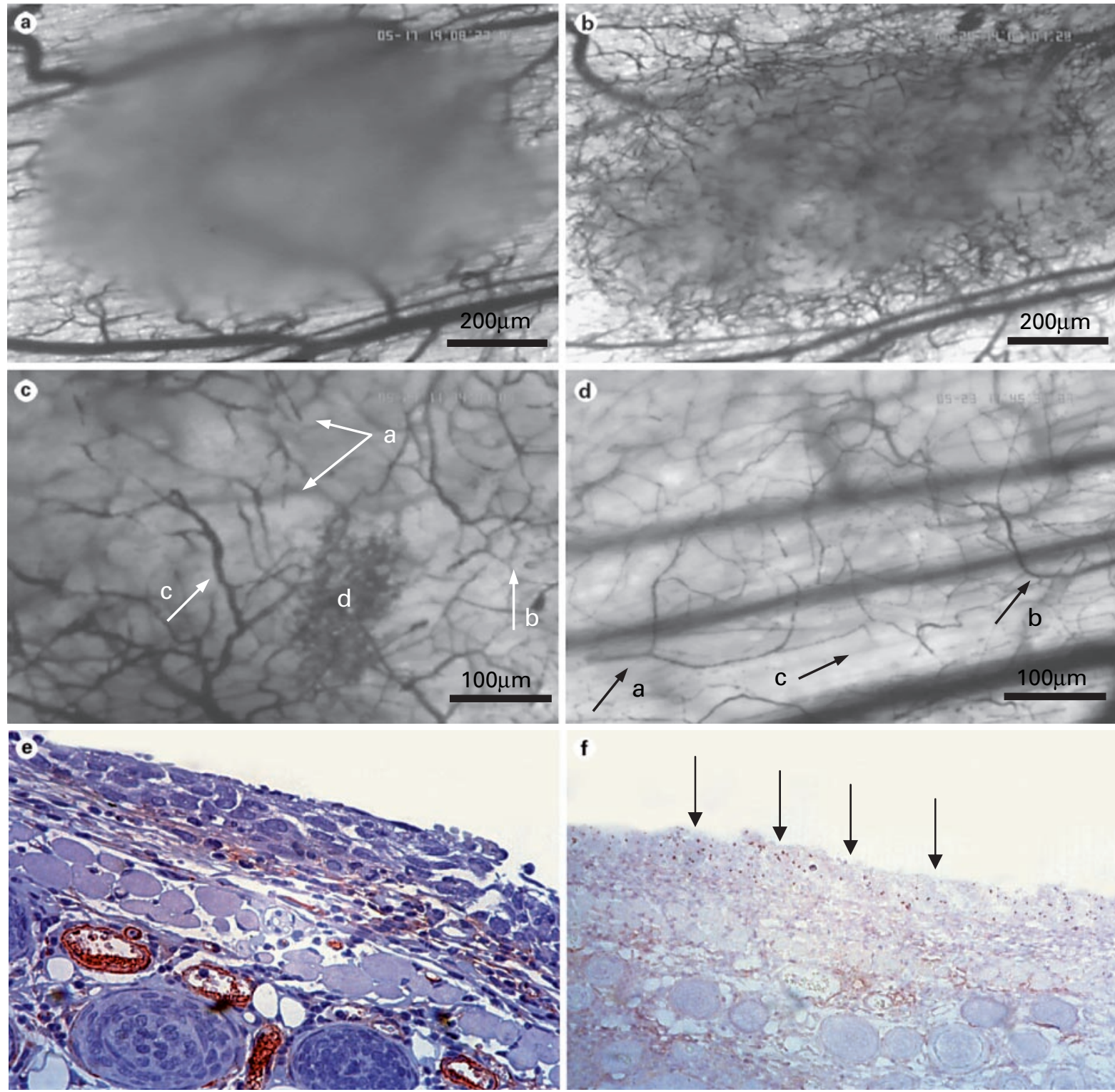

Fig. 6. Analysis of three-dimensional spheroids after implantation into dorsal skinfold chambers. a Aggregate from a bone-marrowderived progenitor cell line (approximately $1 \mathrm{~mm}$ in diameter) $24 \mathrm{~h}$ after implantation into the dorsal skinfold chamber of nude mice. Pictures were obtained by blue-light transillumination, which is absorbed by hemoglobin; blood-filled vessels appear dark against the bright background. No angiogenesis was observed at this time. b The same aggregate 4 days after implantation shows numerous newly formed microvessels sprouting from host vessels and directed to the graft. c Grafts viewed with a higher magnification reveal signs of angiogenesis. The microvasculature is characterized by a heterogeneous angio-architecture with premature vessels: capillary sprouts (a), irregular branching patterns (b), irregular vessel calibers (c) and bleeding $(d)$. d On day 7, the graft is reduced, disclosing the subjacent host muscle; newly formed vessels show signs of maturation: supplying arteriole $(a)$, draining venule $(b)$ and preexisting host capillaries in the striated skin muscle $(c)$. e Longitudinal section of an explanted aggregate side after 7 days in a dorsal skinfold chamber and staining for PECAM-1-positive endothelial cells, which are seen between the implant (top) and the host musculature. f Human centromere-specific in situ hybridization (C17) to detect implanted human cells from the aggregate in the murine dorsal skinfold chamber. 
We transplanted the clonal tissue aggregates into dorsal skin chambers of nude mice. During the 7-day study, the implanted tissue showed no angiogenesis on day 1 (fig. 6a), but neovessel formation with capillary sprouting and branching occurred between days 4 and 7 (fig. 6b-d). On day 7 , the aggregates have largely disappeared, but a mature vessel network remained connected to arterioles and postcapillary venules that apparently originated from capillaries of the underlying striated skin muscle. Time course and morphology of neovessel formation and maturation in our model resembles results found after implantation of syngeneic pancreatic islet cells. In the same model, a xenogeneic reaction was accompanied by rejection and maintenance of both the graft as well as its supplying microvasculature at the same time [Menger et al., 1990], whereas in our study the vessel network was maintained. There was also no significant inflammatory infiltrate.

Like the in vivo adaptation after transplantation of the tissue aggregates to the soft tissue site of the recipient nude mice, angiogenesis occurred particularly at the interface between murine host tissue und implanted human cells (fig. 6e, f).

\section{Discussion}

The degree of plasticity of adult stem cells is still a matter of controversy. However, there is undisputed evidence that adult stem cells can differentiate into various tissues, including the differentiation into endothelial cells during neoangiogenesis [Grant et al., 2002; Otani et al., 2002]. Although most of the multipotent stem cells are routinely isolated from the bone marrow [Pittenger et al., 1999], there is also evidence of circulating CD34-negative, CD45-negative and CD105-positive stem cells in the peripheral blood [Huss et al., 2000]. Differentiation of stem cells can be induced and directed by various in vitro measures, like the application of appropriate growth factors and cytokines or the co-cultivation of stem cells on tissue-inductive scaffolds [Mackay et al., 1998; Bianchi et al., 2001; Li et al., 2001]. Previous experiments on bone formation and vascularized tissues from mesenchymal stem cells were performed with a number of cultured cells consisting of a heterogeneous cell population without evidence of clonality [Dennis et al., 2002; Harris and Cooper, 2004]. We used instead a three-dimensional structure approach to generate bone or bone precursors in vitro [Kale et al., 2000] from human monoclonal human stem cell lines similar to primary cells, as also described by others [Shi et al., 2002]. However, not only can areas of min- eralization be observed in three-dimensional spheroids, blood vessels are also formed and mature in the close interaction of different cell types [Korff et al., 2001], depending on the milieu and local environment [Kaushal et al., 2001]. The implantation of cells and tissues into the dorsal skinfold chamber of T-cell-deficient nude mice (Crl:CD1-nu; Charles River) enables real-time observation of neoangiogenesis and vessel formation together with cell motility in vivo [Lehr et al., 1993]. Previously, the dorsal skinfold chamber was also found to be a suitable model to study cell aggregates such as ovarian follicles [Vollmar et al., 2001] and pancreatic islet cells [Menger et al., 1990]. Although we succeeded in the generation of osteocalcin-positive areas and the establishment of mineralized tissue in our aggregates, no exclusive and mature bone maturation was seen in vitro or in vivo. Nevertheless, the co-expression of osteocalcin and MMP-9 is in accordance with a possible osteoblastic nature of those differentiated stem cells, because osteoblasts also use this proteinase (gelatinase A) for migration and tissue invasion [Festuccia et al., 1999]. Instead of further maturation into bone tissue in vivo, angiogenesis prevailed in both mouse models (implantation of the cell aggregates into the soft tissue and into the dorsal skin chamber) suggesting that the local on-site milieu was in favor of angiogenesis and failed to support or maintain osteogenesis. Apparently, most of the neovascularization stemmed from the host site and formed anastomoses between the murine host and the human graft. Adult stem cells may also induce or facilitate differentiation of preexisting progenitor cells or a subpopulation of precursor cells, e.g. by releasing stimulating and activating cytokines and growth factors, which in turn participate in creating an inflammatory environment which is necessary for the enhancement of arteriogenesis [Harraz et al., 2001; Hartlapp et al., 2001]. Such a growth factor is placental growth factor (PIGF), which is able to recruit preexisting and primed stem cells from other sources or niches like the bone marrow [Hattori et al., 2002] and is able to directly stimulate the formation of arteriogenesis [Pipp et al., 2003]. Bone-marrow-derived stem cells also provide functional hemangioblast activity in vivo [Grant et al., 2002] or modulate the angiogenesis at the lesion site [Otani et al., 2002]. Adult bone marrow cells also contain a subset of CD34-positive Flk-1/ $\mathrm{KDR}(+)$ hemangioblasts [Pelosi et al., 2002], and the impaired recruitment of bone-marrow-derived stem cells interferes with successful angiogenesis [Lyden et al., 2001]. Endothelial progenitors, which still share the CD34 and the flk-1 antigen with hematopoietic precursor cells, have also been isolated from the peripheral blood 
[Asahara et al., 1997] and show enhanced vascular development in the appropriate model, e.g. ischemic tissue [Masuda et al., 2000]. While SCL is a definitive marker for hemangioblasts in zebrafish [Gehring et al., 1998], CD133 has been identified as a marker of peripheral blood cells with either hematopoietic or endothelial potential [Loges et al., 2004].

After trauma, injury or ischemia, neoangiogenesis is the stereotypical response of almost any regenerative tissue. Soluble factors involved in the initiation of angiogenesis and proliferation of endothelial cells are angiopoietin and VEGF [Huang et al., 1999] as well as PlGF, which is also able to revascularize ischemic tissues [Lutton et al., 2002], also by the recruitment of VEGF-receptor-1
(VEGFR1)-positive stem cells from the bone marrow [Hattori et al., 2002]. We also showed that VEGF-positive cells become an integral part of tissue aggregates in vitro, most likely to ensure the survival of stem cells in suboptimal growing conditions, but also to form an angiogenic gradient within the three-dimensional spheroid to attract more stem cells to the area of vasculature and to improve the microcirculatory system in the graft [Harraz et al., 2001; Hartlapp et al. 2001; Huss et al., 2004].

In conclusion, our model has given novel insight into the physiology and plasticity of adult stem cells and mesenchymal tissue derived from monoclonal adult stem cell lines.

\section{References}

Asahara, T., T. Murohara, A. Sullivan, M. Silver, R. van der Zee, T. Li, B. Witzenbichler, G. Schatteman, J.M. Isner (1997) Isolation of putative progenitor endothelial cells for angiogenesis. Science 275: 964-967.

Baron, M.H. (2001) Molecular regulation of embryonic hematopoiesis and vascular development: a novel pathway. J Hematother Stem Cell Res 10: 587-594.

Bianchi, G., A. Muraglia, A. Daga, G. Corte, R. Cancedda, R. Quarto (2001) Microenvironment and stem cell properties of bone marrowderived mesenchymal stem cells. Wound Repair Regen 9: 460-466.

Conrad, C., B. Göttgens, S. Kinston, J. Ellwart, R. Huss (2002) GATA transcription in a small rhodamine 123(low)CD34(+) subpopulation of a peripheral blood-derived CD34(-)CD105(+) mesenchymal cell line. Exp Hematol 30: 887895.

Dennis, J.E., J.P. Carbillet, A.I. Caplan, P. Charbord (2002) The STRO-1+ marrow cell population is multipotential. Cells Tissue Organs 170 : $73-82$.

Festuccia, C., D. Giunciuglio, F. Guerra, I. Villanova, A. Angelucci, P. Manduca, A. Teti, A. Albini, M. Bologna (1999) Osteoblasts modulate secretion of urokinase-type plasminogen activator (uPA) and matrixmetalloproteinase-9 (MMP-9) in human prostate cancer cells promoting migration and matrigel invasion. Oncol Res 11: 17-31.

Gehring, M., A.R.F. Rodaway, G. Göttgens, R.K. Patient, A.R. Green (1998) The SCL gene specifies haemangioblast development from early mesoderm. EMBO J 17: 4029-4045.

Grant, M.B., W.S. May, S. Caballero, G.A.J. Brown, S.M. Guthrie, R.N. Mames, B.J. Byrne, T. Vaught, P.E. Spoerri, A.B. Peck, E.W. Scott (2002) Adult hematopoietic stem cells provide functional hemangioblast activity during retinal neovascularization. Nat Med 8: 607-612.
Harraz, M., C. Jiao, H.D. Hanlon, R.S. Hartley, G.C. Schatteman (2001) CD34-blood-derived human endothelial cell progenitors. Stem Cells 19: 304-312.

Harris CT, L.F. Cooper (2004) Comparison of bone graft matrices for human mesenchymal stem cell-directed osteogenesis. J Biomed Mater Res 68: 747-755.

Hartlapp, I., R. Abe, R.W. Saeed, T. Peng, W. Voelter, R. Bucala, C.N. Metz (2001) Fibrocytes induce an angiogenic phenotype in cultured endothelial cells and promote angiogenesis in vivo. FASEB J 15: 2215-2224.

Hattori, K., B. Heissig, Y. Wu, S. Dias, R. Tejada, B. Ferris, D.J. Hicklin, Z. Zhu, P. Bohlen, L. Witte, J. Hendrikx, N.R. Hackett, R.G. Crystal, M. Moore, Z. Werb, D. Lyden, S. Rafii (2002) Placental growth factor reconstitutes hematopoiesis by recruiting VEGFR1+ stem cells from bone-marrow microenvironment. Nat Med 8: 841-849.

Horwitz, E.M., D.J. Prockop, L.A. Fitzpatrick, W.W.K Koo, P.L. Gordon, M. Neel, M. Sussman, P. Orchard, J.C. Marx, R.E. Pyeritz, M. Brenner (1999) Transplantability and therapeutic effects of bone marrow-derived mesenchymal cells in children with osteogenesis imperfecta. Nat Med 5: 111-116.

Huang, X.L., N. Takakura, T. Suda (1999) In vitro effects of angiopoietins and VEGF on hematopoietic and endothelial cells. Biochem Biophys Res Commun 264: 133-138.

Huss, R., D.S. Hong, P.A. McSweeney, C.A. Hoy, H.J. Deeg (1995) Differentiation of canine marrow cells with hematopoietic characteristics from an adherent stromal cell precursor. Proc Natl Acad Sci USA 92: 748-752.

Huss, R. (1997) Functional and ultrastructural studies on the burst of c-kit ligand containing secretory vesicles. Acta Histochem 99: 111116.

Huss, R. (1998) CD34-negative stem cells as the earliest precursors of hematopoietic progeny. Exp Hematol 26: 1022-1023.
Huss R. (2000) Isolation of primary and immortalized CD34- hematopoietic and mesenchymal stem cells from various sources. Stem Cells 18 : $1-9$.

Huss, R., C. Lange, E.M. Weissinger, H.J. Kolb, K. Thalmeier (2000) Evidence of peripheral blood-derived, plastic adherent CD34-/low hematopoietic stem cell clones with mesenchymal stem cell characteristics. Stem Cells 18: 252260.

Huss, R., M. Heil, S. Moosmann, T. Ziegelhöffer, S. Sagebiel, S. Seliger, S. Kinston, B. Göttgens (2004) Improved arteriogenesis with simultaneous skeletal muscle repair in ischemic tissue by $\mathrm{SCL}+$ multipotent adult progenitor cell (MAP-C) clones from peripheral blood. J Vasc Res 41: 422-431.

Kale, S., S. Biermann, C. Edwards, C. Tarnowski, M. Morris, M.W. Long (2000) Three-dimensional cellular development is essential for ex vivo formation of human bone. Nat Biotechnol 18: 929-930.

Kaushal, S., G.E. Amiel, K. Guleserian, O.M. Shapira, T. Perry, F.W. Sutherland, E. Rabkin, A.M. Moran, F.J. Schoen, A. Atala, S. Soker, J. Bischoff, J.E. Mayer (2001) Functional smalldiameter neovessels created using endothelial progenitor cells expanded ex vivo. Nat Med 7: 1035-1040.

Korff, T., S. Kimmina, G. Martiny-Baron, H.G. Augustin (2001) Blood vessel maturation in a 3-dimensional spheroidal coculture model: direct contact with smooth muscle cells regulates endothelial cell quiescence and abrogates VEGF responsiveness. FASEB J 15: 447-457.

Lange, C., C. Kaltz, K. Thalmeier, H.J. Kolb, R. Huss (1999) Long-term hematopoietic reconstitution of syngeneic mice with a peripheral blood-derived, monoclonal CD34-, Sca-1+, Thy-1 low, c-kit+ stem cell line. J. Hematother Stem Cell Res 8: 335-342. 
Lehr, H.A., M. Leunig, M.D. Menger, D. Nolte, K. Messmer (1993) Dorsal skinfold chamber technique for intravital microscopy in nude mice. Am J Pathol 143: 1055-1062.

Li, Y., T. Ma, D.A. Kniss, S.T. Yang, L.C. Lasky (2001) Human cord cell hematopoiesis in three-dimensional nonwoven fibrous matrices: in vitro stimulation of the marrow microenvironment. J Hematother Stem Cell Res 10: 355368.

Loges, S., B. Fehse, M.A. Brockmann, K. Lamszus, M. Butzal, M. Guckenbiehl, G. Schuch, S. Ergün, U. Fischer, A.R. Zander, D.K Hossfeld, W. Fiedler, U.M. Gehling (2004) Identification of the adult human hemangioblast. Stem Cells Dev 13: 229-242.

Lutton, A., M. Tjwa, L. Moons, Y. Wu (2002) Revascularization of ischemic tissues by PIGF treatment, and inhibition of tumor angiogenesis, arthritis and atherosclerosis by anti-Flt 1 . Nat Med 8: 831-840.

Lyden, D., K. Hattori, S. Dias, C. Coast, P. Blaikie, L. Butros, A. Chadburn, B. Heissig, W. Marks, L. Witte, Y. Wu, D.J. Hicklin, Z. Zhu, N.R. Hackett, R.G. Crystal, M.A.S. Moore, K.A. Hajjar, K. Manova, R. Benezra, S. Rafii (2001) Impaired recruitment of bone-marrow-derived endothelial and hematopoietic precursor cells blocks tumor angiogenesis and growth. Nat Med 7: 1194-1201.

Mackay, A.M., S.C. Beck, J.M. Murphy, F.P. Barry, C.O. Chichester, M.F. Pittenger (1998) Chondrogenic differentiation of cultured human mesenchymal stem cells from marrow. Tissue Eng 4: 415-428.
Masuda, H., C. Kalka, T. Asahara T (2000) Endothelial progenitor cells for regeneration. Hum Cell 13: 153-160.

Menger, M.D., S. Jaeger, P. Walter, F. Hammersen, K. Messmer (1990) A novel technique for studies on the microvasculature of transplanted islets of Langerhans in vivo. Int $\mathbf{J}$ Microcirc Clin Exp 9: 103-117.

Otani, A., K. Kinder, K. Ealt, F.J. Otero, P. Schimmel, M. Friedlander (2002) Bone marrow-derived stem cells target retinal astrocytes and can promote or inhibit retinal angiogenesis. Nat Med 8: 1004-1010.

Pelosi, E., Valtieri M., S. Coppola, R. Botta, M. Gabbianelli, V. Lulli, G. Marziali, B. Masella R. Muller, C. Sgadari, U. Testa, G. Bonanno, C. Peschle (2002) Identification of the hemangioblast in postnatal life. Blood 100: 32033208.

Pipp, F., M. Heil, K. Issbrücker, T. Ziegelhoeffer, S. Martin, J. van den Heuvel, H.H. Weich, B. Fernandez, G. Golomb, P. Carmeliet, W. Schaper, M. Clauss (2003) VEGFR-1-selective VEGF homologue PIGF is arteriogenic: Evidence for a monocytemediated mechanism. Circ Res 92: 378-385.

Pittenger, M.F., A.M. Mackay, S.C. Beck, R.K. Jaiswal, R. Douglas, J.D. Mosca, M.A. Moorman, D.W. Simonetti, S. Craig, D. Marshak (1999) Multilineage potential of adult human mesenchymal stem cells. Science 276: 318 321.

Singer, J.W., A. Keating, J. Cuttner, A.M. Gowan, R. Jacobson, P.D. Killen, J.W. Moohr, V. Najfeld, J. Powell, J. Sanders (1984) Evidence for a stem cell common to hematopoiesis and its in vitro microenvironment: studies of patients with clonal hematopoietic neoplasia. Leuk Res 8: 535-545.
Shi, S., S. Gronthos, S. Chen, A. Reddi, C.M. Counter, P.G. Robey, C.Y. Wang (2002) Bone formation by human postnatal bone marrow stromal stem cells is enhanced by telomerase. Nat Biotechnol 20: 587-591.

Thalmeier, K., P. Meissner, G. Reisbach, L. Hültner, B.T. Mortenson, A. Brechtel, R.A. Oostendorp, P. Dörmer (1996) Constitutive and modulated cytokine expression in two permanent human bone marrow stromal cell lines. Exp Hematol 24: 1-9.

Thalmeier, K., P. Meissner, S. Moosmann, S. Sagebiel, I. Wiest, R. Huss (2001) Mesenchymal differentiation and organ distribution of established human stromal cell lines in NOD/SCID mice. Acta Haematol 105: 150-165.

Vollmar, B., M.W. Laschke, R. Rohan, J. Koenig, M.D. Menger (2001) In vivo imaging of physiological angiogenesis from immature to preovulatory ovarian follicles. Am J Pathol 159: 1661-1670.

Zhang, S.C., M. Wernig, I.D. Duncan, O. Brüstle, J.A. Thomson (2001) In vitro differentiation of transplantable neural precursors from human embryonic stem cells. Nat Biotechnol 19: 1129-1133.

Ziegler, B.L., M. Valtieri, G.A. Porada, R. De Maria, R. Muller, B. Masella, M. Gabbianelli, I. Casella, E. Pelosi, T. Bock, E.D. Zanjani, C. Peschle (1999) KDR receptor: a key marker defining hematopoietic stem cells. Science 28 . 1553-1558. 